\title{
A CONSPECTUS OF MEXICAN MELANTHIACEAE INCLUDING A DESCRIPTION OF NEW TAXA OF SCHOENOCAULON AND ZIGADENUS
}

\author{
Dawn Frame \\ Laboratoire de Botanique, ISEM \\ Institut de Botanique \\ 163, rue A. Broussonet \\ 34090 Montpellier \\ France \\ e-mail: aurora@isem.univ-montp2.fr \\ Adolfo Espejo \\ Y \\ Ana Rosa Lopez-FerRari \\ Herbario Metropolitano \\ Departamento de Biología, CBS \\ Universidad Autónoma Metropolitana \\ Unidad Iztapalapa \\ Apartado postal 55-535 \\ 09340 México, D.F. \\ e-mail: aes@xanum.uam.mx
}

\begin{abstract}
Seven new taxa of Schoenocaulon and one more of Zigadenus from Mexico are herein described. In addition, a brief description of the Mexican genera of Melanthiaceae and a key to genera and species known from Mexico are given.
\end{abstract}

\section{RESUMEN}

Se describen siete nuevos taxa de Schoenocaulon y uno de Zigadenus provenientes de diversos estados de México. Se incluyen claves para la identificación de los géneros y de las especies de la familia presentes en México y se hacen algunos comentarios breves sobre los mismos.

The Melanthiaceae sensu Dahlgren et al. (1985) are a medium-sized family (25 genera, ca. 150 species) of herbaceous lily-like plants comprising six tribes: Petrosavieae, Melanthieae, Narthecieae, Tofieldieae, Chionographideae, and Xerophylleae. Although the first author has considerable reservations of treating what was formerly a subfamily of 
Liliaceae as a distinct family --in a separate order if we are to believe Dahlgren et al. (1985)-- the alignment of genera, with the notable exception of the inclusion of the curious wholly tropical tribe Petrosavieae, is fairly standard (see Hutchinson, 1959; Krause, 1930) and the group a natural one. The family is essentially north temperate but with some extensions into the tropics. Recently proposed further subdivision of Melanthiaceae into three families (Zomlefer, 1997), is untenable.

Only tribe Melanthieae is represented in Mexico with four of six genera: Schoenocaulon A. Gray, Stenanthium (A. Gray) Kunth, Veratrum L., and Zigadenus Michx. (Table 1). The 31 Mexican species (34 taxa) mostly grow in mid- to high elevations of the Sierra Madre Occidental, Sierra Madre Oriental and Eje Volcánico Transmexicano. Of the two genera not present in Mexico, Amianthium, is monotypic and Melanthium would be better reduced to a section of Veratrum. It is the genus Schoenocaulon that is most impressively expressed in Mexico. Apparently most closely related to Zigadenus, a genus best developed in the Pacific coast and related regions of North America, Schoenocaulon has undergone considerable evolutionary diversification in Mexico and includes approximately 24 species (Frame, 1990), five of which are formally described here.

Table 1. Species number by genus, of the Melanthiaceae present in Mexico.

\begin{tabular}{|l|c|c|c|}
\hline Genera & Total species & Mexican species & Mexican endemics \\
\hline Schoenocaulon A. Gray & 24 & 23 & $18(78.26 \%)$ \\
Stenanthium (A. Gray) Kunth & 4 & 1 & $1(100 \%)$ \\
Veratrum L. & 25 & 1 & $0(0 \%)$ \\
Zigadenus Michx. & 16 & 6 & $4(66.66 \%)$ \\
\hline Total & 69 & $31(44.9 \%)$ & $23(74.19 \%)$ \\
\hline
\end{tabular}

\section{KEY TO THE MEXICAN GENERA OF MELANTHIACEAE}

1 Plants having a bulb-rhizome, fibers enveloping the bulb usually coarse and thick, hiding the truncate woody rhizome; flowers sessile or subsessile at anthesis, arranged in a spicate inflorescence, generally dense, at least distally Schoenocaulon

1 Plants having bulbs or rhizomes, rarely both, and bulb enveloped in papery leaf bases; flowers distinctly pedicellate at anthesis and arranged in panicles, mostly lax.

2 Plants having a rhizome; pseudo-stem formed prior to flowering; leaves ovate; seeds with a membranaceous wing Veratrum

2 Plants having a bulb; no pseudo-stem formed prior to flowering; leaves linear to linearlanceolate; seeds never winged.

3 Flowers white to yellowish or greenish; tepals rounded Zigadenus

3 Flowers dark purple, rarely greenish tinged; tepals narrowly acuminate 
Frame et al.: Conspectus of Mexican Melanthiaceae Including Descriptions of New Taxa

\section{SCHOENOCAULON A. Gray}

With the exception of four, species of this genus are entirely endemic to Mexico (Frame, 1990). Of those not confined to Mexico, two extend into Texas, one of which just reaches New Mexico; one grows south to Perú and Venezuela; and one species is endemic to Florida. Plants usually growing at elevations above 1000 meters in chaparral, oak, pineoak or pine forests on calcareous or volcanic soils.

Specimens of this genus are comparatively scarce in herbarium collections; this is both a reflection of the rarity of most species and the generally inconspicuous appearance of the plants, specially when not in flower. Plants often form small colonies in rocky places. Some of the most valuable diagnostic features for recognition of species are to be found in the inflorescence, particularly its length and diameter at anthesis and also in the flower, especially the morphology of the nectaries and tepals.

Revision of the genus as part of a doctoral thesis (Frame, 1990) has led to the proposal of the following new taxa:

Schoenocaulon caricifolium (Schltdl.) A. Gray var. oaxacense Frame, var. nov. Fig. 1.

A var. caricifolio plantis solitariis vel in coloniam parvam aggregatis, floribus polline primo liberato sessilibus, necnon perianthii segmentis late falciformibus differt.

Plants forming small colonies of a few bulbs, or growing singly; flowers sessile when pollen is first being shed; tepals broadly falciform.

Calcareous soil in dry woodland of the Mixteca Alta. Growing in leaflitter of scrub oak and madrone. Elevation 2100-2350 m. Flowering May through July and fruiting late July through mid-September.

TYPE: Mexico, Oaxaca, Distrito Teposcolula, $6 \mathrm{~km}$ SW of Tamazulapan along road to Chilapa de Díaz, D. Frame \& A. García Mendoza 289 (holotype: NY; isotypes: ENCB, $\mathrm{GH}, \mathrm{K}, \mathrm{MEXU}, \mathrm{MICH}, \mathrm{P}, \mathrm{UC}, \mathrm{US})$.

Paratypes: Mexico, Oaxaca, DistritoTeposcolula, cerro Llano Redondo, $0.8 \mathrm{~km} \mathrm{~S}$ of Teposcolula, D. Frame et al. 271 (NY); Distrito Teposcolula, cerro Llano Redondo, 0.8 km S of Teposcolula, A. García Mendoza 1111 (ENCB); Distrito Teposcolula, slope below Pan-am hwy at Puerto Herrera, just NW of Yanhuitlán, H. H. Iltis et al.1130 (WIS); Distrito Teposcolula, $3 \mathrm{~km}$ SW of Tamazulapan on road to Chilapa, A. García Mendoza \& D. Lorence 715 (ENCB, MEXU).

After repeated examination of the material and analysis of the chromosomes and chemistry, it has been decided to recognize the Oaxacan representatives of Schoenocaulon caricifolium as a distinct variety.

Schoenocaulon ignigenum Frame, sp. nov. Fig. 2.

Inter congeneres bulbi tunica superne abrupte attenuata, foliis angustis scapo brevioribus, perianthii segmentis 2.4-3.2 mm longis flavo-virentibus vel atrovinoso-nigris et 


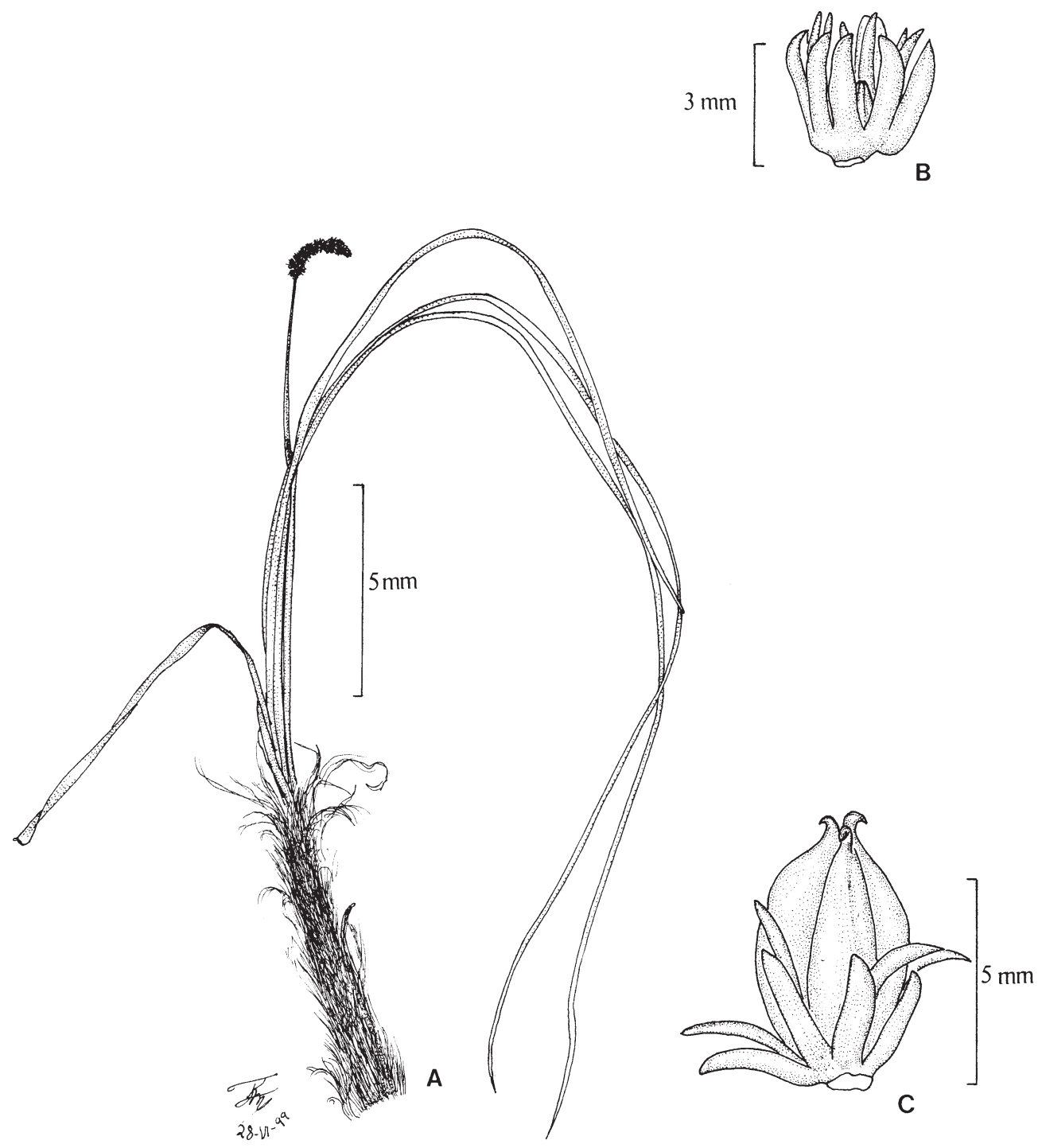

Fig. 1. Schoenocaulon caricifolum var. oaxacense. A. Habit; B. Functionally staminate flower without anthers; C. Fruit. 
Frame et al.: Conspectus of Mexican Melanthiaceae Including Descriptions of New Taxa

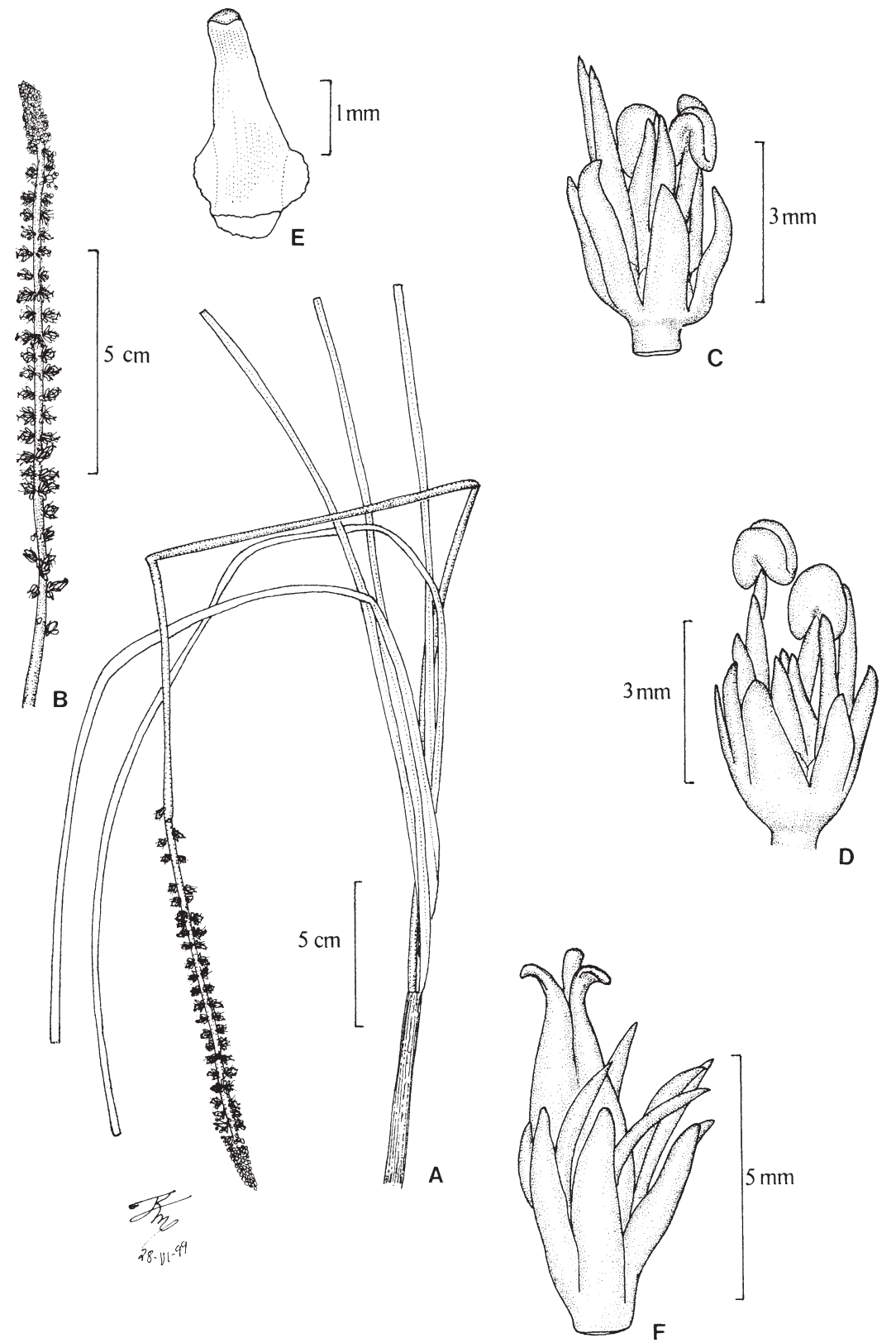

Fig. 2. Schoenocaulon ignigenum. A. Habit; B. Inflorescence; C and D. Functionally staminate flowers; E. Tepal; F. Fruit. 
auriculorum margine maxima ex parte crenatis, necnon filamentis maturis 4.2-4.7 mm longis insigniter distinguitur.

Bulb ellipsoid, 1-2.5 cm long and 1-3 cm in diameter, enveloped underground by layers of fine to moderately coarse dark brown fibers, these forming a narrow tunic 9$13 \mathrm{~cm}$ long and 0.4-1.2 cm in diameter; leaves 3-8, 17-38 cm long and 1.6-3.7(-5) mm wide, mostly shorter than the scape, green, 8-12(-16)-nerved, the nerves spaced 0.05$0.3 \mathrm{~mm}$ apart; scape $20-40 \mathrm{~cm}$ long and 1.5-3 $\mathrm{mm}$ in diameter, green to green-purple, usually becoming darker purple toward and within the inflorescence, the moderately loose 67-130-flowered raceme 9-17 cm long; flowers 5-6-ranked, when pollen is first being shed pedicelled, the pedicels $0.3-0.6 \mathrm{~mm}$ long and 0.6-1.2 $\mathrm{mm}$ in diameter, purple-green, the uppermost 8-35 flowers functionally staminate, the uppermost 6-18 bracts empty or concealing rudimentary flowers and forming a short narrow crown or often this missing and the raceme terminated by a staminate flower; bracts broadly ovate to nearly pentagonal, purple-magenta, 1-5.3 mm long and 2-3.5 mm wide, membranous to slightly fleshy, with 4-7 wine- to rust-colored veins, margin crenate to erose; tepals varying from ligulate to ovate-hastate, $2.4-3.2 \mathrm{~mm}$ long, at base canaliculate adaxially and 0.4-0.6 mm wide, at middle plane $0.6-0.9 \mathrm{~mm}$ wide, at tip cucullate and $0.2-0.3 \mathrm{~mm}$ wide, distally yellow-green to dark purple and proximally purple-brown to dark purple, usually with a single median vein, rarely 3 -veined; auricles present, the margin usually crenate; filaments when pollen is first being shed just surpassing the tepals, maturing one by one, continuing to elongate to $4.2-4.7 \mathrm{~mm}$, magenta; unopened anthers narrowly sagittate, purple-peach; gynoecium when pollen is first being shed ellipsoid to narrowly ovoid, 2.4-3.4 mm long and 1.3-1.5 mm in diameter, white; ovules 8-13 per locule, placenta occupying the lower two-thirds of ovary suture; when pollen is first being shed, styles including stigmas, 0.5$0.7 \mathrm{~mm}$ long; nearly mature to mature capsules unknown.

Scattered on rocky limestone hillsides and ridges in open pine forests of the Sierra de Agua de Afuera and adjacent heights in the Sierra Madre Oriental of Nuevo León and Tamaulipas. Elevation 2400-3110 m. Flowering June through August and fruiting August through October. Endemic to the periodically burned mountain tops and as its name implies, $S$. ignigenum is adapted to regenerate after the lightening fires of common occurence in that part of the Sierra Madre Oriental, to which it is endemic.

TYPE: Mexico, Tamaulipas, municipio of Miquihuana, between Marcela and Valle Hermoso; burned-over area, L. R. Stanford, S. M. Lauber \& L. A. Taylor 2626 (holotype: US; isotypes: DS, RSA).

Paratypes: Mexico, Nuevo León, District of Zaragoza, San Onofre, G. B. Hinton et al. 17581 (ENCB); Tamaulipas, municipio of Miquihuana, $4 \mathrm{~km} \mathrm{~W}$ of Miquihuana, L. R. Stanford, K. L. Retherford \& R. D. Northcraft 637 (DS, GH, MO, NY, UC).

Schoenocaulon ignigenum is distinguished by short narrow leaves, short tepals of unusual color with crenulate auricles, and short filaments. The tunic in this species provides another important character. As the fine to medium-coarse fibers which thickly envelop the 
Frame et al.: Conspectus of Mexican Melanthiaceae Including Descriptions of New Taxa

bulb approach the soil surface, they diminish considerably, forming a very thin coat at the soil-surface interface. The change is abrupt and usually occurs a few to several centimeters below the ground level. It is likely that this abrupt thinning of the tunic is related to burning. Either the heat penetrates below the ground, or over time the contractile roots have pulled the bulb deeper underground, or both.

Schoenocaulon madidorum Frame, sp. nov. Fig. 3.

Inter congeneres tunica 7-20 cm longa, foliis glaucis mollibus 7-13 maxima ex parte scapo longioribus, nervis $12-13$ bene separatis percursis, inflorescentia modice condensata, perianthii segmentis auriculatis, nectario maturo basi in quoque perianthii segmento globoso vel cordato, nectare copioso, ovulis in quoque loculo 4-8, et seminibus in quoque loculo 1 (2) insigniter distinguitur. Amat loca humida, in pineto-quercetis.

Bulb ellipsoid to plumpy ellipsoid, $3-4.5 \mathrm{~cm}$ long and $2-4 \mathrm{~cm}$ in diameter, enveloped underground by layers of papery dark brown leaf bases, these forming a neck $7-20 \mathrm{~cm}$ long and $1-2.5 \mathrm{~cm}$ in diameter of moderately coarse brown to dark brown fibers, often up to half of the neck emergent; leaves 7-13, 52-100 cm long and (4-) 7-10.5 mm wide, usually equalling or surpassing the raceme, blue-green to green, mostly soft and pliant, 12-13-nerved, the nerves spaced 0.5-1.1 mm apart; scape 20-68 cm long and 1.5-7 $\mathrm{mm}$ in diameter, the moderately condensed (35-) 70-200-flowered raceme 14-27 cm long; flowers 4-5-ranked, when pollen is first being shed pedicelled, the pedicels $0.8-1.5 \mathrm{~mm}$ long and $0.6-0.9 \mathrm{~mm}$ in diameter, the uppermost 15-40 flowers functionally staminate, the uppermost 10-40 bracts empty or concealing rudimentary flowers, forming a small dome crowning the inflorescence, or rarely this missing and the inflorescence terminated by a poorly-formed flower; bracts broadly ovate to pentagonal, 2.4-3.2 $\mathrm{mm}$ long and 2-3.5 mm wide, membranous, with 67 wine-colored veins, margin crenulate to erose; pedicels of nearly mature to mature capsules usually gently curving upwards to dispose the fruit not quite parallel to scape or sometimes irregularly disposing fruit at right angles to scape, 3-4.5 mm long and 1-1.5 mm in diameter, those of any vertical rank $10-15 \mathrm{~mm}$ apart; tepals in outline proximally irregularly cuneate and distally subulate to linear, green to pinkish green or purple-green, blade fleshy, when pollen is first being shed 2.9-4.1 mm long, at base adaxially canaliculate and 0.4$0.7 \mathrm{~mm}$ wide, at middle plane and $0.4-0.7 \mathrm{~mm}$ wide, at tip cucullate and $0.15-0.3 \mathrm{~mm}$ wide; auricles one-half to two-thirds of tepal width at its widest place and one-third to nearly onehalf of tepal length, margin entire to irregularly crenate; when pollen is first being shed nectary varying from a smooth depression to a spherical or cordate pit, later a distinct pit variable in outline, obscurely to distinctly 3 -veined, usually one vein visible at blade tip; tepals usually continuing to elongate to $4.2-5.3 \mathrm{~mm}$ long; when pollen is first being shed the filaments surpassing the tepals, white, continuing to elongate to $5-9 \mathrm{~mm}$ long, turning magenta; unopened anthers sagittate; gynoecium when pollen is first being shed ovoid to ampulliform, 3.2-4.5 $\mathrm{mm}$ long and 1.4-1.6 $\mathrm{mm}$ in diameter, white, there after often turning pinkish; ovules 4-8 per locule, placenta ocupying the lower one-half to two-thirds of ovary suture; when pollen is first being shed styles, including stigmas, 0.8-1.1 mm long; capsules plumpy ellipsoid to nearly globose, $8-13 \mathrm{~mm}$ long and $5-10 \mathrm{~mm}$ in diameter, when nearly mature to mature usually raised with the filaments $0.5-0.7 \mathrm{~mm}$ above the perianth, beaked 


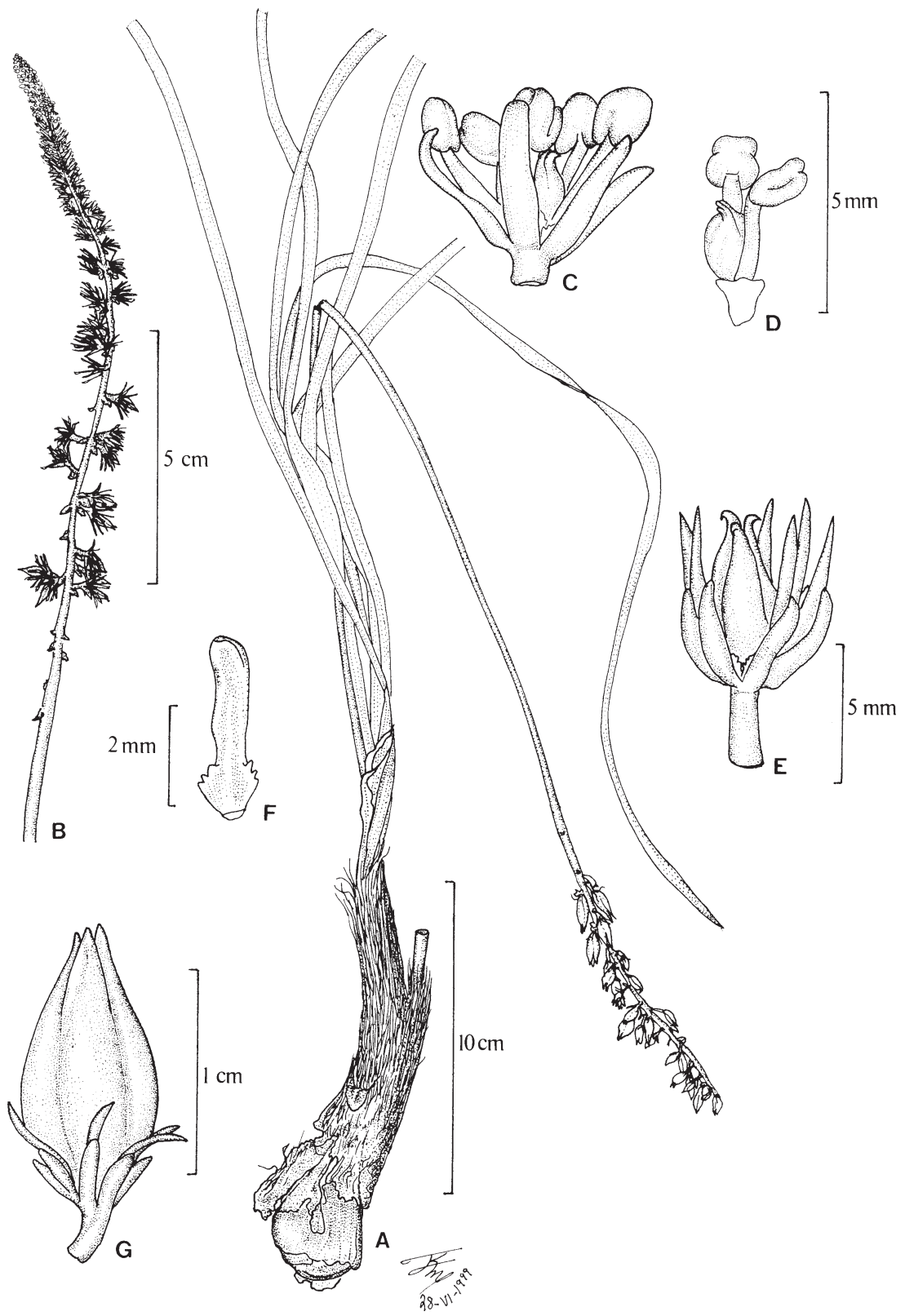

Fig. 3. Schoenocaulon madidorum. A. Habit; B. Inflorescence; C. Functionally staminate flower; D. Stamens; E. Flower with immature ovary; F. Tepal; G. Fruit. 
Frame et al.: Conspectus of Mexican Melanthiaceae Including Descriptions of New Taxa

by styles, including stigmas, 0.5-1 mm long; seeds 1(2) in each locule, plumpy ellipsoid to ellipsoid or conic, $5-9 \mathrm{~mm}$ long and $2-3.2 \mathrm{~mm}$ in diameter, chestnut, minutely rugose to reticulate-foveate.

Endemic to Mexico, in pine-oak forests in Puebla and Veracruz as well in Oaxaca. Growing among calcareous rocks in semidry to moist places. Elevation 1900-3000 m. Flowering May through July and fruiting June through October.

TYPE: Mexico, Puebla, municipio of Tepetzintla, Cerro Chiquinahuimazatl, W of Tepetzintla, P. Tenorio et al. 13851 (holotype: UC; isotype: MEXU).

Paratypes: Mexico, Oaxaca, Distrito de Etla, cañada de San Gabriel, C. Conzatti \& V. González $323(\mathrm{GH})$; Puebla, Sierra de Zacapoaxtla, L. Diguet s. n. (ENCB, MICH); municipio of Esperanza, Boca del Monte, C. A. Purpus 2490 (UC); municipio of Tetela de Ocampo, $8 \mathrm{~km}$ SE of Tetela, on dirt road to Apulco, P. Tenorio et al. 14298 (UC); Veracruz, municipio of Huayacocotla, El Paraje, R. Hernández et al. 874 (MEXU), municipio of Huayacocotla, Huayacocotla-Texcatepec, Turra 936 (ENCB); municipio of Maltrata, carretera de Orizaba a Puebla, J. Fay et al. 754 (F); municipio of Maltrata, Maltrata, E. Matuda 1346 (F, MICH, NY, US); municipio of Orizaba, Uluapa, Orizaba, F. Müller 231 (NY).

This species has sometimes been confused with $S$. officinale (Schltdl. et Cham.) A. Gray ex Benth., perhaps because it has well-defined nectaries (at least in the later stages of flower maturation) and because the ranges of the two species are nearly coincident in the vicinity of Orizaba, Veracruz. Notwithstanding, S. madidorum is amply distinct. Early on, its nectaries appear as smooth depressions or deep pits near the base of the tepals; later a deep pit is always discernible. These nectaries produce copious nectar which appears in herbarium specimens as honey-like drops on the adaxial surface of tepals. Also the presence of basal auricles in the tepals and the green to pinkish-green or purple-green flowers distinguish it from $S$. officinale. In striking contrast to those of all other species in the genus, the nectaries of $S$. officinale are distinctive thick pads, presumably formed by the amplification of underlying cell layers. These pads conceal the vascular bundles and there are no honey-drops of nectar on herbarium specimens of $S$. officinale.

Schoenocaulon madidorum is found on moist upland places, for which it is named. The long wide soft pliant leaves, distinctive tepals from which copious nectar is produced, long filaments, striking long pedicels, and plump fruits make it readily recognizable.

Schoenocaulon megarrhizum M. E. Jones var. deminutum Frame, var. nov.

A var. megarrhizo bulbis minimis in coloniam aggregatis, inflorescentis maxima pro parte brevibus, et statura plerumque minore diversa.

Plants relatively small and delicate, growing in clumps; bulb $1.5-3 \mathrm{~cm}$ long and 1$2.7 \mathrm{~cm}$ in diameter; the inflorescence no more than $18 \mathrm{~cm}$ long.

Sierra Madre Occidental in Durango and Nayarit. Growing in pine-oak forest. Elevation ca. 2300 m. Flowering August. 
TYPE: Mexico, Durango, municipio of Santiago Papasquiaro, Santiago Papasquiaro, E. Palmer 419 (holotype: GH; isotypes: F, MO, NY, UC, US).

Paratype: Mexico, Nayarit, near Santa Teresa, top of Sierra Madre, J. N. Rose 2227 (NY, US). The collection locality for Rose 2227 is given on the US duplicates as "from near Santa Teresa"; however, the label of the NY specimen reads "collected in the state of Durango", which is probably a mistake.

The specimens collected near Santiago Papasquiaro and Santa Teresa clearly represent a different sort of Schoenocaulon megarrhizum than do plants which grow further north and west in the Sierra Madre Occidental. The plants from Durango and Nayarit, are united on the base of their similarity in stature and habit, and in these respects are readily distinguishable from var. megarrhizum.

Schoenocaulon plumosum Frame, sp. nov.

Inter congeneres bulbo minimo vel raro magno squamis et foliorum reliquiis brunneis vel fuscobrunneis papiraceis involucrato, foliis 6-11 angustis et modice longis, scapo inflorescentia modice condensata longiore, floribus in racemi dimidio vel tertio superiore masculinis, perianthii segmentis 2.1-3.2 mm longis pallide viridibus vel atrovinoso-brunneis, nectariis leviter definitis, filamentis $5.5-7 \mathrm{~mm}$ longis, albidis vel lavandulis et postea magenteis vividis, antea dehiscentiam antheris magenteis vividis et postea atromagenteis demum saepe reflexis, ovulis in quoque loculo 10-12 insigniter distinguitur.

Gently tapering bulb ellipsoid to transversely ellipsoid, $1.7-6 \mathrm{~cm}$ long and $1.5-5 \mathrm{~cm}$ in diameter, enveloped underground by layers of light to dark brown papery leaf bases, these forming a neck 7-20 cm long and 0.6-2.2 cm in diameter, of dark brown papery to moderately coarse fibers; leaves 6-11, 47-125 cm long and 2-8 mm wide, green to green-blue, often shorter than the raceme, 10-20 nerved, the nerves spaced 0.2-0.5 mm apart; scape 38$76 \mathrm{~cm}$ long, 1.2-4.8(-5.6) $\mathrm{mm}$ in diameter, green at base usually turning brilliant purple to purple-brown toward and within the inflorescence, the moderately condensed (54-)75-245flowered raceme 10.5-30 cm long; flowers 5-6-ranked, when pollen is first being shed pedicelled, the pedicels $0.4-1.2 \mathrm{~mm}$ long and $0.4-1 \mathrm{~mm}$ in diameter, the uppermost onethird to one-half of the flowers functionally staminate, the uppermost 14-32(-100) bracts empty or concealing rudimentary flowers and forming a plump to narrow crown; bracts broadly ovate to pentagonal, 1.6-2.6 mm long and 1.9-2.2 mm wide, membranous, with 47 wine- to rust-colored veins, margin entire to crenulate or erose; pedicels of nearly mature to mature capsules curving abruptly upwards to dispose fruit mostly parallel to scape, 1.5$2.5 \mathrm{~mm}$ long and 0.7-1.1 $\mathrm{mm}$ in diameter, those of any vertical rank 9-11 mm apart; tepals varying from distally subulate to ligulate and proximally cuneate to oblong or linear and nearly lacking auricles, pale green to purple-brown, proximally usually less herbaceous and nearly translucent and distally slightly fleshy, when pollen is first being shed $2.1-3 \mathrm{~mm}$ long, at base adaxially canaliculate and 0.3-0.6 mm wide, at middle plane 0.4-0.6 mm wide, at tip plane to slightly cucullate and $0.1-0.3 \mathrm{~mm}$ wide; nectary appearing as a moderately deep 
Frame et al.: Conspectus of Mexican Melanthiaceae Including Descriptions of New Taxa

to deep lunate-shaped depression; veins at base 3 , the lateral ones often expiring distal to auricles, median vein expiring short of the tip; when pollen is first being shed the filaments nearly twice as long as the tepals, white to pale lavender, later usually brilliant magenta or rarely remaining white, when fully expanded 5.5-7 $\mathrm{mm}$ long; unopened anthers sagittate, brilliant magenta, opened anthers dark magenta, often reflexed before abscission; gynoecium when pollen is first being shed narrowly ampulliform, 2.5-4.5 mm long and 0.8$1.8 \mathrm{~mm}$ in diameter, white to pale levander, carpels well-sealed; ovules 10-12 per locule, placenta occupying three-fourths to nearly entire ovary suture; when pollen is first being shed styles, including stigmas, $0.4-1.5 \mathrm{~mm}$ long; usually gynoecium raised with the filaments to $0.6 \mathrm{~mm}$ above the perianth; capsules plumpy ellipsoid, $8.2-10 \mathrm{~mm}$ long and $3.5-5.3 \mathrm{~mm}$ in diameter, often tinged magenta-purple, beaked by styles, including stigmas $0.9-1.3 \mathrm{~mm}$ long; seeds 1-2 in each of 2-3 locules, ellipsoid to falciform, 5-6.3 mm long and 1-1.4 mm in diameter, dark red-chestnut, rugose-reticulate, with both ends crowned by a light-brown membranous appendage.

Limestone slopes of the Sierra Madre Oriental, in Coahuila, Nuevo León, and Tamaulipas. Growing on steep cliffs and bluffs in shade under rock ledges or under scrub oaks. Elevation 700-1690 m. Flowering July through October and fruiting August through November. The sinuous inflorescence coupled with the rapid early expansion of white turning to purple-pink filaments suggests the plume of some exotic bird and provides the metaphor for this species name.

TYPE: Mexico, Nuevo León, municipio of Linares, shady rock ledges of limestone cliff, Sierra Madre Oriental, 21 miles W of Linares, H. D. D. Ripley \& R. C. Barneby 13565 (holotype: NY; isotypes: CAS).

Paratypes: Mexico, Coahuila, municipio of Arteaga, near Coahuila-Nuevo León border, dry roadside bank, $4.8 \mathrm{~km}$ W of La Nogalera on road from Saltillo to Cola de Caballo, D. Frame 394A (NY); Tamaulipas, municipio of San Carlos, Pico del Diablo, vicinity of Marmolejo, H. H. Bartlett 10918 (MICH, US); municipio of Aldama, Los Cerritos to La Borada (Sierra de San Juan), ca. 40 km NNW of Aldama, R. Dressler 2005 (GH); municipio of Tula, $10 \mathrm{~km} \mathrm{NW}$ of El Progreso, which is $18 \mathrm{~km} \mathrm{NW}$ of Ocampo, L. R. Stanford et al. $1055(\mathrm{GH}$, $\mathrm{MO}, \mathrm{NY}$ ); Nuevo León, municipio of San Pedro García, Chipinque Park, near the suburb by the same name which lies just south of Monterrey, D. Frame 388 (NY); municipio of General Zaragoza, Dulces Nombres, Nuevo León and just east of border into Tamaulipas, F. G. Meyer \& D. J. Rogers $2776(\mathrm{GH}, \mathrm{MO})$; trail to Puerta, Mountains near Monterrey, C. H. Mueller \& M. T. Mueller $12(\mathrm{~F})$; municipio of Montemorelos, east slope of Sierra de la Cebolla, C. H. Mueller $2885(\mathrm{GH})$.

Schoenocaulon plumosum is recognizable by papery leaf bases of the bulb, relatively few and generally narrow long leaves, often plume-like inflorescence with one-third to onehalf of the upper flowers functionally staminate, flowers with relatively short pedicels, pale green to purple-brown moderately-sized narrow tepals with poorly defined nectaries, conspicuous purple to brilliant magenta filaments, and plumpy ellipsoid fruits of moderate 
size. Perhaps most likely to be confused with S. macrocarpum Brinker or S. madidorum, its nearest relatives, $S$. plumosum clearly differs by having shorter tepals, and generally fewer and more narrow leaves.

Schoenocaulon rzedowskii Frame, sp. nov. Fig. 4.

Inter congeneres bulbo minimo, scapo crasso, inflorescentia plerumque in praecoci statu florendi, perianthii segmentis cum canalibus longis 2-3, ovulis in quoque loculo 6-9, capsulis magnis ellipsoideis vel late ellipsoideis, et seminibus in quoque loculo 1-3 insigniter distinguitur.

Shallowly buried bulb plumpy ellipsoid to ovoid, $1.5-3 \mathrm{~cm}$ long and $1.5-2 \mathrm{~cm}$ in diameter, enveloped underground by moderately coarse brown fibers, these gradually constricted into a neck $3-10 \mathrm{~cm}$ long and 6-12 mm in diameter; leaves 7-9, 40-55 cm long and 2.5-5 $\mathrm{mm}$ wide, usually longer than the raceme, green, (9-) 11-15-nerved, the nerves spaced 0.2-0.4 mm apart; scape 19-42 cm long and (1.7-) 2-4.7 mm in diameter, green to green-purple, the moderately loose to slightly condensed $34-80$-flowered raceme 10.5 $15 \mathrm{~cm}$ long; flowers when pollen is first being shed pedicelled, the pedicels $0.3-0.4 \mathrm{~mm}$ long and $0.4-0.6 \mathrm{~mm}$ in diameter, the uppermost 2-30 flowers functionally staminate, the uppermost 6-20 bracts empty or concealing rudimentary flowers forming a poorly-developed crown; bracts broadly ovate, 2.3-3.4 mm long and 2.8-3.1 mm wide, membranous, with 57 wine-colored veins, margin denticulate to crenulate; pedicels of nearly mature to mature capsules curving upwards to dispose fruit parallel to scape, 1.5-3 mm long and 1-1.5 mm in diameter, those of any vertical rank $12-15 \mathrm{~mm}$ apart; tepals distally linear to ellipsoid and proximally cuneate, $3-4.8 \mathrm{~mm}$ long, often continuing to elongate during anthesis, green to green-magenta, adaxially canaliculate with $2-3$ channels, at base $0.5-0.6 \mathrm{~mm}$ wide, at middle 0.4-0.7 mm wide, at tip cucullate and 0.3-0.4 mm wide, strongly 3-veined, the auricles welldeveloped, each about one-quarter to one-half of blade width and up to one-quarter of blade length; when pollen is first being shed, the filaments surpassing the tepals, when mature 4-5.7 mm, and magenta; unopened anthers unknown; gynoecium when pollen is first being shed, 2-2.2 mm long and 1-1.1 mm in diameter; ovules 6-9 per locule, placenta occupying two-thirds of ovary suture; when pollen is first being shed, styles, including stigmas, 0.3$0.4 \mathrm{~mm}$ long; capsules ellipsoid to plumpy ellipsoid, $15-20 \mathrm{~mm}$ long and $7-9 \mathrm{~mm}$ in diameter, beaked by styles, including stigmas, $0.5-0.7 \mathrm{~mm}$ long; seeds 1-3 in each locule, ovoid to conic, 5-7.5 mm long and 2-2.8 mm in diameter, golden chestnut to chestnut or dark brown, rugose to rugose-ruminate.

Hills in the Puebla and Tepeaca valleys in the state of Puebla, and in the southeastern valleys in the state of México. Rare in disturbed grassy habitat, and abundant in undisturbed sclerophyllous scrub. Mostly growing in black soil on limestone rocks, or sometimes in claylimestone soil. Elevation 2250-2470 m. Flowering June through July and fruiting July through September.

The species honors Dr. Jerzy Rzedowski, who has a deep appreciation of the Mexican flora. 
Frame et al.: Conspectus of Mexican Melanthiaceae Including Descriptions of New Taxa

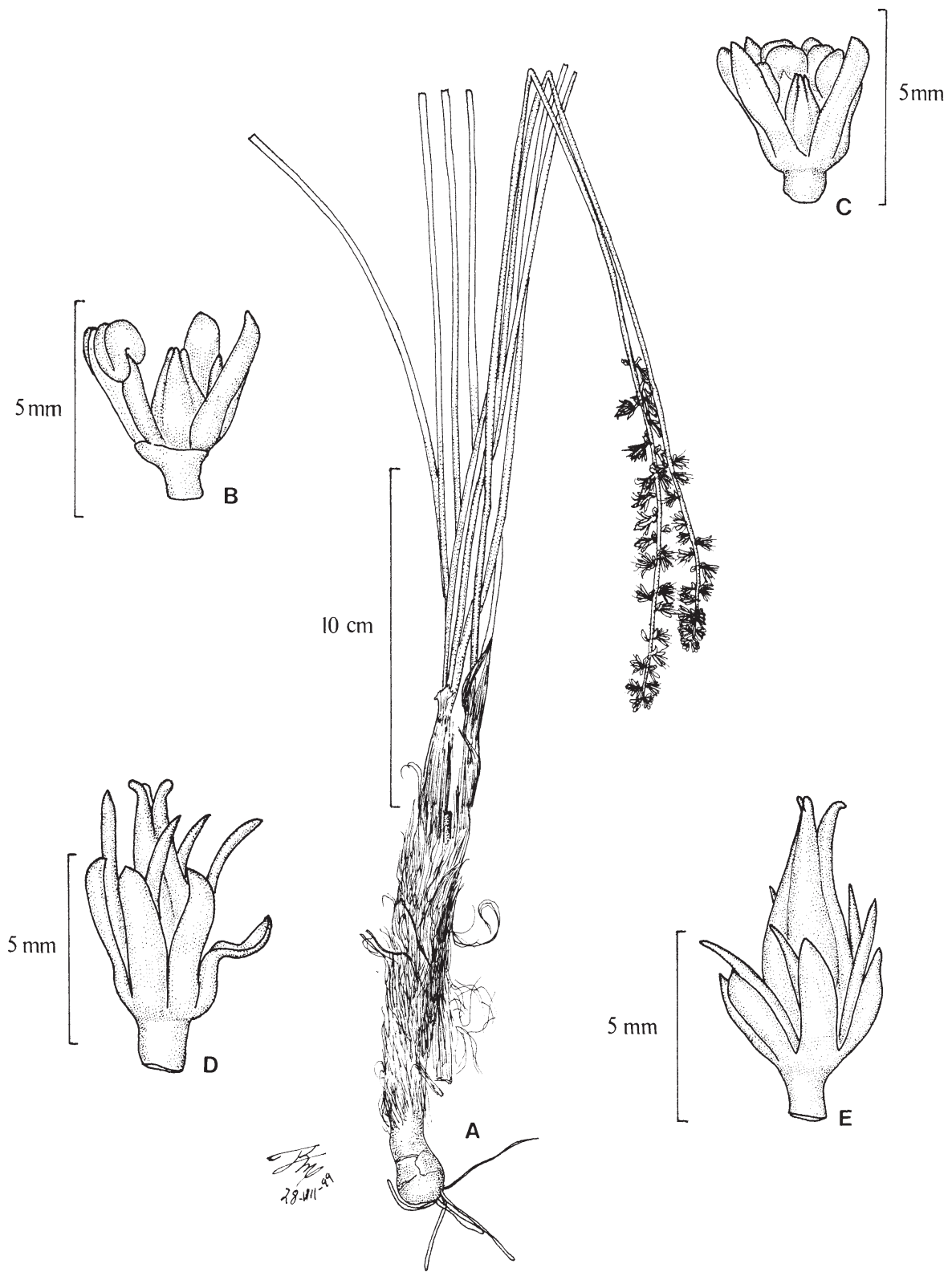

Fig. 4. Schoenocaulon rzedowskii. A. Habit; B and C. Functionally staminate flowers; D. Flower with immature ovary; E. Fruit. 
TYPE: Mexico, Puebla, municipio of Puebla, Cerro Amalucan, near Chapultepec, 8 km E of Puebla, J. Rzedowski 24138 (holotype: MICH; isotypes: DS, ENCB, F, WIS).

Paratypes: Mexico, México, municipio of Texcoco, cerro Tetzcutzingo, $8 \mathrm{~km} \mathrm{E}$ of Texcoco, D. Frame \& R. Galván 245 (NY); municipio of Texcoco, Cerro Tetzcutzingo, 8 km al E de Texcoco, M. T. Pulido S. 483 (ENCB); Puebla, municipio of Puebla, Cerro Amalucan, near Chapultepec, $8 \mathrm{~km} \mathrm{E}$ of the city of Puebla, public park on outskirts of city, $D$. Frame \& P. Tenorio 387 (ENCB, NY); "Manzanilla", F. Nicolás 5302 [additional label reads "vicinity of Puebla, G. Arsène 5302" but has "collector" scratched out] (US); vicinity of Puebla, G. Arsène s. n. (US) [duplicate of F. Nicolás 5302?]; municipio of Tecamachalco, cerro east of Tecamachalco, P. Tenorio et al. 14160 (MEXU)

Schoenocaulon rzedowskii is distinguished by its small shallowly buried bulb, stout scape, tepals with 2-3 channels running the length of the blade, proportionately small gynoecium when the pollen is first being shed, and relatively large ellipsoid to plumpy ellipsoid fruits with rather plump seeds. Continued collecting in undisturbed places in the valleys of Puebla and México will perhaps yield several more populations of this rare species.

Schoenocaulon tenorioi Frame, sp. nov.

Inter congeneres statura minima, foliis 4-6 angustis, pedicellis brevissimis, racemo laxo, perianthii segmentis ovatis vel distalibus obovatis et proximalibus quasi cuneatis brevibus (2.1-2.4 mm) carnosis, capsula late elliptica vel globosa 5-9.5 mm longa et scapo non adpressa, et seminibus in quoque loculo 1-2 insigniter distinguitur.

Bulb narrowly ovoid, 1-2 cm long and 1-1.2 cm in diameter, enveloped underground by papery leaf bases, these forming a neck 3.3-7 cm long and $0.4-1 \mathrm{~cm}$ in diameter of fine grayish brown to brown fibers; leaves 4-6, $14-24 \mathrm{~cm}$ long and 1.5-2.5 mm wide, usually equalling or just surpassing the inflorescence, green, 7-11-nerved, the nerves spaced 0.1 $0.3 \mathrm{~mm}$ apart; scape 14-20 cm long and 1-1.6 mm in diameter, barely tapering, straw-colored becoming red-purple to purple-brown toward and within the inflorescence, the loose 12-50flowered raceme 5-9 cm long; flowers 3-ranked, when pollen is first being shed, sessile to subsessile, the pedicels no more than $0.4 \mathrm{~mm}$ long, the uppermost 8-10 flowers functionally staminate, the uppermost 2-10 bracts empty or concealing rudimentary flowers and forming a small crown; bracts narrowly triangular to broadly ovate, $2-2.3 \mathrm{~mm}$ long and $2.4-2.7 \mathrm{~mm}$ wide, membranous, with 6-8 wine-colored veins, margin crenulate to erose; pedicels of mature capsules ascending 45-60 from stem, 0.7-1.2 mm long and 0.7-0.8 mm in diameter, those of any vertical rank $11-14 \mathrm{~mm}$ apart; tepals ovate to distally obovate and proximally nearly cuneate, 2.1-2.4 mm long, at base adaxially canaliculate and 0.7-1 mm wide, at tip cucullate blunt to acute and 0.1-0.3 mm wide, blade thick and fleshy, upon rehydration often with a distal crease, green, green to purple at margin, veins obscure; auricles barely perceptible to each one-third to one-half of tepal length and about one-fifth of tepal width at widest place, margin entire to crenate; nectaries appearing as a distinct lunate to round depression or pit; when pollen is first being shed, the filaments just surpassing the tepals, white, when mature 2.5-3.3 mm long, subulate; unopened anthers reniform to cordate, 
yellow-magenta; gynoecium when pollen is first being shed, ovoid, 3.5-3.6 mm long and 1.6-1.7 $\mathrm{mm}$ in diameter, white to white-pink or slightly greenish; ovules 6-7 per locule, placenta occupying the lower one-half to two-thirds of ovary suture, carpels loosely cohesive; when pollen is first being shed styles, including stigmas, 0.3-0.6 mm long; capsules plumpy ellipsoid to globose, $5-9.5 \mathrm{~mm}$ long and $3.2-7 \mathrm{~mm}$ in diameter, beaked by styles, including stigmas, 0.3-0.4 mm long; seed(s) 1-2 in each locule, ovoid to conic, $2.8-5 \mathrm{~mm}$ long and 1.5-2.2 $\mathrm{mm}$ in diameter; golden orange-brown to golden chestnut, striate-rugose to rugosereticulate.

Open dry rocky hills to the north and south of the Tehuacán valley in Puebla and Oaxaca. Growing around scrubby herbs in rocky white limestone. Elevation 1950-2250 m. Flowering July through August and fruiting August through September. Schoenocaulon tenorioi appears to be endemic to the hills rimming the Tehuacán valley. Named after PedroTenorio L., naturalist and intrepid plant collector who specializes in the flora of the states of Puebla and Oaxaca.

TYPE: Mexico, Oaxaca, El Rodeo, foothills at the southern base of Cerro Verde, NE of Tlacotepec, D. Frame et al. 344 (holotype: NY; isotypes: K, MEXU, UC, US).

Paratypes: Mexico, Puebla, municipio of Vicente Guerrero, $6 \mathrm{~km}$ NW of Nicolás Bravo along dirt road to Azumbilla, P. Tenorio et al. 14128 (MEXU); Oaxaca, Cerro Verde, one day's journey by horse from El Rodeo, NE of Tlacotepec, D. Frame et al. 345 (K, MEXU, NY, UC); Ibid., C. A. Purpus 4389 (UC).

The plants of Schoenocaulon tenorioi are distinctly colonial, but because they are small, their colonies are not extensive. The species is immediately recognizable by its small stature, narrow leaves, short loose inflorescence, short pedicels, green fleshy tepals, and small plumpy ellipsoid to globose fruits which are not appressed to the stem. S. tenorioi appears to be closely related to $S$. caricifolium (Schltdl.) A. Gray and S. calcicola Greenm.

\section{KEY TO THE MEXICAN TAXA OF SCHOENOCAULON}

1 Tepals red to red-green or magenta-green; flowers campanulate in outline

S. tenuifolium

1 Tepals cream, green, green-cream, green-yellow, green-pink, green-purple, bluish green, purple, or purple-brown; flowers not campanulate.

2 Tepals cream.

3 Perigonal nectaries well-developed, appearing as thick pads at tepal base; tepals fleshy and opaque ....................................................................... S. officinale

3 Perigonal nectaries poorly-developed, appearing as shiny nectariferous tissue at tepal base; tepals petaloid to slightly fleshy and usually translucent

S. pellucidum

2 Tepals green, green-cream, green-yellow, green-pink, green-purple, bluish green, purple or purple-brown. 
4 Tepal margin undulate to crenulate or minutely denticulate, auricles essentially lacking; tepals often nearly petaloid.

5 Filaments at least twice the length of the tepals, usually dilated above. Widespread

S. ghiesbreghtii

5 Filaments 1.5 times the length of the tepals, subulate. Endemic to the Sierra del Tigre, in south-central Jalisco

S. tigrense

4 Tepal margin entire, auricles usually present and margin variable from entire to crenulate; tepals usually slightly fleshy to fleshy, sometimes herbaceous.

6 Tepals dark purple or purple-brown, sometimes only so proximally; if perianth faded and appearing green-brown, the tepals usually with a single median vein and the auricle margin crenate.

7 Filaments at maturity just surpassing tepals. Endemic to regions of exposed granite outcrops north of Pachuca, Hidalgo S. obtusum

7 Filaments at maturity about 1.5 times the length of the tepals.

8 Tepals purple, fleshy, and with indistinct auricles which form raised lateral edges along the basal channel

S. intermedium

8 Tepals purple to purple-brown, mostly herbaceous to proximally slightly fleshy, auricles distinct to nearly lacking.

9 Tepals distinctly auriculate, the auricle margin usually crenate; tunic neck tapering (often abruptly) to $3-7 \mathrm{~mm}$ in diameter as it approaches soil surface. Endemic to the open pine forests of the Sierra de Agua de Afuera and adjacent heights in the Sierra Madre Oriental of Nuevo León and Tamaulipas

S. ignigenum

9 Tepals auriculate to barely so, the auricle margin not noticeably crenulate; tunic neck not tapering significantly as it approaches soil surface, fairly widespread

S. plumosum

6 Tepals green, green-cream, green-yellow, green-purple, or bluish-purple, mostly 3-veined, auricle margin entire to crenate.

10 Inflorescence loose, the flowers well-separated from each other along the inflorescence axis.

11 Plants of very small stature; inflorescence axis at most $30 \mathrm{~cm}$ long; bulbfibers papery to fine.

12 Leaves 14-24 cm long; tepals with poorly-developed auricles; capsules plumpy ellipsoid to globose, not appressed to inflorescence axis. Puebla and Oaxaca ........................................... S. tenorioi

12 Leaves $30-45 \mathrm{~cm}$ long; tepals with well-developed auricles; capsules ovoid to ellipsoid, appressed to inflorescence axis. Endemic to the volcanic hills in the region of Tepoztlán, Morelos S. tenue

11 Plants of small to relatively large stature; inflorescence axis greater than $30 \mathrm{~cm}$ long, or if shorter then bulb-fibers very coarse.

13 Plants very robust; filaments at maturity $7.3-8 \mathrm{~mm}$ long. Endemic to Cerro San Felipe, Oaxaca

S. conzattii

13 Plants generally less robust; filaments at maturity no more than $6.2 \mathrm{~mm}$, or rarely the plants robust and the filaments to $7 \mathrm{~mm}$ at maturity. 
Frame et al.: Conspectus of Mexican Melanthiaceae Including Descriptions of New Taxa

14 Plants with coarse horsehair-like bulb-fibers; inflorescence attenuate and approximately equalling the scape in lenght

S. comatum

14 Plants with papery to coarse bulb-fibers; inflorescence not attenuate, or if rarely the bulb-fibers very coarse and the inflorescence attenuate, then the scape much longer than the inflorescence.

15 Flowers distinctly pedicellate when pollen is first being shed; pedicels at least $0.6 \mathrm{~mm}$ long.

16 Unopened anthers green; tepals bluish-green to greenpurple; ovary green, later green-purple

S. jaliscense

16 Unopened anthers yellow to peach or peach-purple; tepals green to green-cream or green- purple; ovary white, later pink to pink-purple.

17 Pedicels strongly curving to orient capsules close, and becoming slightly appressed to inflorescence axis; scape very sturdy and plants appearing somewhat coarse.

18 Tepals distally spreading, green

S. megarrhizum

18 Tepals not spreading, green-cream

S. pellucidum

17 Capsules not appressed to inflorescence axis nor pedicels strongly curving; scape flexuous when young, plants appearing long and delicate

S. calcicola

15 Flowers sessile to subsessile when pollen is first being shed, the pedicels when present no more than $0.6 \mathrm{~mm}$ long.

19 Flowers strictly sessile when pollen is first being shed. Jalisco and San Luis Potosí

S. jaliscense

19 Flowers subsessile when pollen is first being shed; pedicels no more than $0.6 \mathrm{~mm}$ long.

20 Tepals with indistinct auricles which form raised edges to the basal channel; carpels loosely sealed; immature capsules often brilliant magenta-purple

S. intermedium

20 Tepals distinctly auriculate; carpels well-sealed; immature capsules generally green to greenpurple, or rarely purple-green.

21 Tepals distally spreading; inflorescence very loose; scape long and slender; small- plumpy ellipsoid to globose capsules not appressed to inflorescence axis

S. calcicola 
21 Tepals not distally spreading; inflorescence moderately loose; scape varying from long, relatively thick and slightly tapering to distinctly stout and hardly tapering; capsules various and appressed to inflorescence axis.

22 Scape relatively thick, at least at base, and tapering; plants tall and robust or rarely relatively short, and the inflorescence attenuate; tepals not channeled along their length. S. mortonii

22 Scape distinctly stout and hardly tapering in fruit; plants relatively short; inflorescence not attenuate; tepals adaxially canaliculate with 2-3 channels S. rzedowskii

10 Inflorescence moderately condensed to very condensed, the flowers crowded along the infloresence axis.

23 Inflorescence relatively short and comparatively few-flowered, no more than than $12 \mathrm{~cm}$ long with up to 65 flowers.

24 Inflorescence very condensed, with nearly no expansion between the green to green-yellow flowers, and forming a distinctly 5-ranked tight spiral; stamens just emergent. Endemic to the pine-tussock grass communities of the Transmexican Volcanic Belt S. pringlei

24 Inflorescence condensed, but generally with a little expansion between the flowers, and a spiral not readily discernable; filaments at least 1.5 times the length of the tepals.

25 Scape relatively short, no more than $30 \mathrm{~cm}$ long, rarely to $42 \mathrm{~cm}$ but then very stout and hardly tapering; inflorescence slightly condensed to condensed.

26 Fruits appearing inflated, plumpy ellipsoid to globose and not closely appressed to the inflorescence axis; mature filaments white to pale pink S. caricifolium

26 Fruits generally not inflated, or if so then ellipsoid to plumpy ellipsoid and closely appressed to the inflorescence axis; mature filaments usually bright magenta.

27 Tepals distinctly auriculate, and adaxially canaliculate with 2-3 channels; inflorescence only slightly condensed; when in fruit, scape very stout and hardly tapering S. rzedowskii

27 Tepals with or without auricles, but never adaxialy canaliculate with 2-3 channels; inflorescence condensed; when in fruit, scape usually tapering often from a moderately thick base S. texanum

25 Scape relatively long, at least $35 \mathrm{~cm}$, and gently tapering; inflorescence condensed.

28 Flowers brightly colored, uppermost one-third to one-half functionally staminate; immature to mature capsule usually 
raised with the filaments above the perianth; inflorescence often flexuous; leaves generally many and long, 6-11 and 47-125 cm long

S. plumosum

28 Flowers usually not very brightly colored, usually only the uppermost 1-12 flowers functionally staminate, rarely more if flowers withered; immature to mature capsule rarely raised with the filaments above the perianth, usually only so if flowers withered or ovules aborted; inflorescence usually erect; leaves usually few and relatively short, (3-)58 and $15-60 \mathrm{~cm}$ long

S. texanum

23 Inflorescence relatively long and many-flowered, usually at least $12 \mathrm{~cm}$ long with more than 65 flowers.

29 Leaves relatively wide and pliant, mostly $7-10.5 \mathrm{~mm}$ wide; pedicels of immature to mature capsules noticeably long and thin, $3-4.5 \mathrm{~mm}$ long and 1-1.5 mm in diameter; flowers usually producing copious nectar

S. madidorum

29 Leaves wide or narrow, but if relatively wide not soft and pliant; pedicels of immature to mature capsules mostly less than $3 \mathrm{~mm}$, or if longer then the tepals pale green-cream; flowers not producing copious nectar.

30 Tepals pale green to green-cream; scape at least a meter long

S. pellucidum

30 Tepals green to green-purple, or if pale green then scape much less than a meter tall.

31 When pollen is first being shed, tepals at least $3 \mathrm{~mm}$ long; bulb shallowly to deeply buried, if deeply buried then the immature to mature capsule raised with the filaments above the perianth.

32 Tepals distinctly long and narrow, often with barely discernable auricles; immature to mature capsule raised with the filaments above the perianth; plants mostly robust with many broad leaves; inflorescence condensed

S. macrocarpum

32 Tepals various, but not strikingly narrow, and often distinctly auriculate; immature to mature capsule only very rarely raised with the filaments above the perianth, usually only so if flowers withered or ovules aborted; plants relatively small to rarely large and robust, leaves mostly relatively few and narrow; inflorescence slightly condensed to condensed.

33 Tepals distinctly auriculate, and adaxially canaliculate with 2-3 channels; inflorescence only slightly condensed; when in fruit, scape very stout and hardly tapering S. rzedowskii

33 Tepals with or without auricles, but never adaxially canaliculate with 2-3 channels; inflorescence 
condensed; when in fruit, scape usually tapering often from a moderately thick base.

S. texanum

31 When pollen is first being shed, tepals usually less than $3 \mathrm{~mm}$ long, or if slightly longer, the bulb deeply buried and the immature to mature capsule not raised with the filamentes above the perianth.

34 Immature to mature capsule usually raised with the filaments above the perianth; bulb usually shallowly buried; inflorescence condensed. Limestone soils S. plumosum

34 Immature to mature capsule not raised with the filaments above the perianth; bulb usually deeply-buried; inflorescence slightly condensed. Volcanic soils S. mortonii

\section{STENANTHIUM (A. Gray) Kunth}

A genus comprising four species (Kupchan et al., 1961; Utech, 1987), two of which are restricted to the United States and southern Canada (Stenanthium occidentale A. Gray, S. gramineum (Ker) Morong), one grows in eastern Asia (S. sachalinense Schmidt) and one, Stenanthium frigidum (Schltdl. \& Cham.) Kunth is endemic to the Eje VolcánicoTransmexicano in central Mexico (Table 1).

The tall and stout plants of $S$. frigidum inhabit in the high zones of the central Mexican mountains between 2700 and $3700 \mathrm{~m}$ in pine forests and the species is the southernmost member of the tribe Melanthieae. The branched andromonoecious, bracted panicle of $S$. frigidum with their pendulous dark purple flowers distinguish clearly this elusive and rare species.

\section{VERATRUM L.}

Veratrum is essentially a circumboreal genus of approximately 25 species (Kupchan et al., 1961). The sole species present in Mexico is Veratrum californicum Durand, a big and stout plant that reaches $2.5 \mathrm{~m}$ high and is common in low to high mountain meadows from western United States to northern Mexico. Adapted to cool climates, it grows in the temperate forests of the states of Chihuahua and Durango. Specimens of this species are extremely scarce in Mexican herbarium collections, which is a reflection of the rarity of the species.

\section{ZIGADENUS Michx.}

A mostly American genus of approximately 16 species (Walsh, 1936), of bulbous perennial scapose or subescapose herbs, with racemose or paniculate inflorescences that 
Frame et al.: Conspectus of Mexican Melanthiaceae Including Descriptions of New Taxa

grow in temperate forests generally above $2000 \mathrm{~m}$. Walsh (1936) cited five species and two varieties from Mexico, Espejo \& López-Ferrari (1996) listed nine species and Hess \& Sivinski (1995) included a key for all members of the section Anticlea, but they never mention specifically the total number of the species for Mexico. Currently, we consider that there are six recognized Mexican species (Table 1), including the new taxon here proposed, but this number may increase with continued collecting and modern revisionary work on this poorly understood genus.

Zigadenus neglectus Espejo, López-Ferrari \& Ceja, sp. nov. Fig. 5.

Plantae 50-90(-100) cm altae, bulbi anguste ovoidei, folia basalia 3-8, viridia attenuata, inflorescentiam non superantia; flores nutantes, tepalis albis ellipticis $4.5-5.2 \mathrm{~mm}$ longis $1.6 \mathrm{~mm}$ latis, nectariis aspectu duorum pulvinorum flavorum ad dimidium tepalorum positis, filamentis maturis $4-6 \mathrm{~mm}$ longis, tepala superantibus.

Plants 50-90(-100) cm tall, bulb narrowly ovoid, 2-2.5 cm long and 1.2-1.7 cm in diameter, enveloped underground by papery leaf bases; basal leaves 3-8, 26-55 cm long and 5-16 mm wide, usually not surpassing the panicle, green, attenuate; scape $30-60 \mathrm{~cm}$ long and ca. $2 \mathrm{~mm}$ in diameter, the loose many flowered panicle $30-45 \mathrm{~cm}$ long, branches thin, spreading-ascending, 8-12 cm long; scape bracts 1-2, leafy, 7.5-21 cm long and 4.5$6.5 \mathrm{~mm}$ wide; flower bracts lanceolate, $4-13(-18) \mathrm{mm}$ long and 1-1.5 mm wide, scarious; flowers cernuous, pedicellate, the pedicels decurved, $1.1-2 \mathrm{~cm}$ long at anthesis; tepals white, elliptic, 4.5-5.2 mm long and ca. $1.6 \mathrm{~mm}$ wide, rounded at tip, margin entire, central vein yellow; nectaries appearing as two yellow oblong pads at the middle of tepals; the filaments surpassing the tepals, white, when mature 4-6 mm long, subulate; unopened anthers cordiform to cordate, yellow; gynoecium superior, ovoid, 4-5 mm long and 1-1.5 mm in diameter, white or slightly yellowish; ovules 1-2 per locule, carpels cohesive; styles, including stigmas, 1.5-1.7 mm long; capsules and seeds not seen.

TYPE: Mexico, Guanajuato, municipio of Xichú, Puerto del Manzanar, Sierra de Xichú, E. Ventura \& E. López 9560 (holotype: UAMIZ isotypes: IEB).

Paratypes: Mexico, Guanajuato, municipio of Xichú, Charco Azul, E. Ventura \& E. López 8645 (IEB, UAMIZ); Edo. de México, municipio of Almoloya de Alquisiras, ca. $3 \mathrm{~km}$ W of Plan de Vigas, and ca. $2 \mathrm{~km}$ E of El Potrero, A. Espejo et al. 3817 (UAMIZ); Querétaro, municipio of Pinal de Amoles, Cerro de la Calentura, N of El Madroño, E. Carranza 2542 (IEB, UAMIZ); municipio of Jalpan, 4-5 km S of La Parada, El Pilón, B. Servín 1594 (IEB, UAMIZ).

Zigadenus neglectus inhabits temperate forests in the Mexican states of Guanajuato, México, and Querétaro. Elevation 1400-2520 m. Flowering August through October. The species is recognizable by its small pendulous white flowers disposed in loose panicles, yellow nectaries at the middle of tepals, stamens longer than tepals and tepals not over $6 \mathrm{~mm}$ long. The name makes reference to the long time neglected species. 


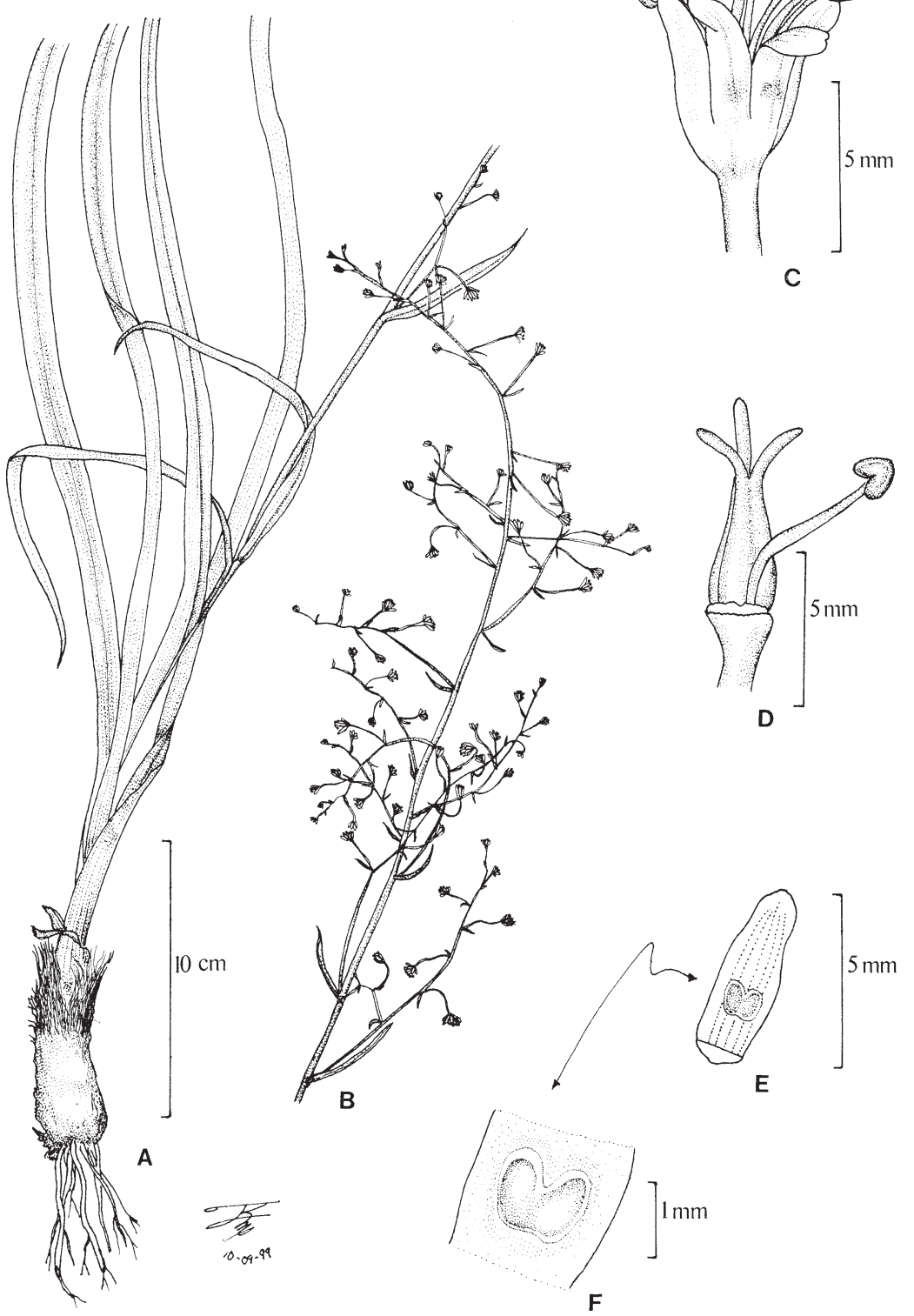

Fig. 5. Zigadenus neglectus. A and B. Habit and inflorescence; C. and D. Flower; E and F. Tepal with central nectary. 
Frame et al.: Conspectus of Mexican Melanthiaceae Including Descriptions of New Taxa

The next combination is also necessary for the correct definition of Mexican taxa.

Zigadenus virescens (Kunth) J. F. MacBr. var. porrifolius (Greene) O. S. Walsh ex Espejo \& López-Ferrari, comb. et stat. nov. Basionym: Zigadenus porrifolius Greene, Bull. Torrey Bot. Club 8: 123. 1881. Anticlea porrifolia (Greene) Rydb., Bull. Torrey Bot. Club 30: 273. 1903. Type: United States, New Mexico, [Socorro Co.], Mogollon Mountains, near the summits, H. Rusby 406 (CAS, GH!, NY ex DH, US 940710).

\section{KEY TO THE MEXICAN TAXA OF ZIGADENUS}

1 Flowers mostly small, $8-12 \mathrm{~mm}$ in diameter, tepals not over $6 \mathrm{~mm}$ long.

2 Inflorescence a raceme, usually dense, simple, rarely with a few branches at base; flowers and pedicels erect at anthesis; stamens as long or shorter than tepals; plants known only from northern Baja California .................................... Z. venenosus

2 Inflorescence a panicle, usually loose; flowers cernuous and pedicels decurved at anthesis; stamens longer than tepals; plants known from the Mexican Plateau

Z. neglectus

1 Flowers larger, $12-30 \mathrm{~mm}$ in diameter; tepals more than $6 \mathrm{~mm}$ long.

3 Stamens longer than tepals.

4 Tepals 1-2 mm wide, 7-8 mm long; stamens all of the same length; bulb dark, $12-$ $18 \mathrm{~mm}$ long ..................................................... Z. virescens var. virescens

4 Tepals 2-4 mm wide, 6-7 mm long; stamens unequal, 3 longer and 3 shorter; bulb whitish, $15-25 \mathrm{~mm}$ long ........................................ Z. virescens var. porrifolius

3 Stamens as long or shorter than tepals.

5 Perianth free from ovary, rarely adherent at extreme base

Z. fremontii

5 Perianth persistently coherent to lower portion of ovary.

6 Flowers erect; tepals broad, 8-14 mm long; tepal gland solitary

Z. elegans

6 Flowers cernuous; tepals narrow, 6-10 mm long; tepal glands two

Z. volcanicus

\section{ACKNOWLEDGEMENTS}

We wish to express our thanks to Victoria Sosa and Jerzy Rzedowski for critical comments and helpful suggestions to the manuscript. We also express our gratitude to the curators of the herbaria ENCB, GH, IEB, MEXU, UAMIZ, US, and XAL for placing the facilities at our disposal, in addition to their kind assistance. The figures were elaborated by Rolando Jiménez Machorro.

\section{LITERATURE CITED}

Bentham, G. \& J. D. Hooker. 1883. Genera plantarum. Vol. 3 part 2. Reeve. London.

Brinker, R. R. 1942. Monograph of Schoenocaulon. Ann. Missouri Bot. Gard. 29: 287-314. 
Dahlgren, R. M. T., H. T. Clifford \& P. E. Yeo. 1985. The families of the Monocotyledons. Structure, evolution and taxonomy. Springer-Verlag. Berlin. 520 pp.

Dalla Torre, C. G. de \& H. Harms. 1900-1907. Genera siphonogamarum. W. Engelmann. Leipzig. pp. 60-61.

Espejo, A. \& A. R. López Ferrari. 1996. Melanthiaceae In: Las monocotiledóneas mexicanas, una sinopsis florística 1. Lista de referencia. Parte VI. Dioscoreaceae a Nolinaceae. Consejo Nacional de la Flora de México, A. C., Universidad Autónoma Metropolitana-Iztapalapa, Comisión Nacional para el Conocimiento y Uso de la Biodiversidad. México, D. F. 116 pp.

Frame, D. 1990. A revision of Schoenocaulon (Liliaceae: Melanthieae). Ph. D. Thesis. The City University of New York. New York. 269 pp.

Hess, W. J. \& R. C. Sivinski. 1995. A new species of Zigadenus (Liliaceae) from New Mexico, with additional comments on the section Anticlea. Sida 16: 389-400.

Hutchinson, J. 1959. The families of flowering plants. Vol. 2. Monocotyledons. 2d. ed. Clarendon Press. London. $792 \mathrm{pp}$.

Krause, K. 1930. Melanthioideae, In: Engler, A. \& K. Prantl, Die natürlichen Pflanzenfamilien 15a: 260266.

Kupchan, S. M., J. H. Zimmerman \& A. Afonso. 1961. The alkaloids and taxonomy of Veratrum and related genera. Lloydia 24: 1-26.

Martínez, M. 1957. Una especie de Veratrum en Durango. Bol. Soc. Bot. Méx. 20: 14-15.

Utech, F. H. 1987. Biosystematic studies in Stenanthium (Liliaceae: Veratreae) II. Floral morphology, floral vascular anatomy, geography and taxonomy of the Mexican S. frigidum (Schlecht. \& Cham.) Kunth. Ann. Carnegie Mus. 56: 197-212.

Walsh, O. 1936. A systematic study of the genus Zigadenus Michx. Ph. D. Thesis. University of California. Berkeley $270 \mathrm{pp}$.

Zomlefer, W.B. 1997. The genera of Melanthiaceae in the southeastern United States. Harvard Papers in Botany 2 (2): 133-177.

Aceptado para publicación en septiembre de 1999. 